\title{
Philosophy of Innovation: A Research Agenda
}

\section{Guest Editorial}

\author{
Vincent Blok ${ }^{1}$
}

Published online: 20 November 2017

(C) Springer International Publishing AG, part of Springer Nature 2017

Innovation is all-pervasive in this day and age. Innovative companies like Apple and Google are heralded, like scientists and artists in previous ages, and inspire a lifestyle in which the status quo is challenged and no limits are accepted upfront. While new business development and innovative entrepreneurship is appreciated and encouraged, policy-makers foster innovation as well: "We need to do much better at turning our research into new and better services and products if we are to remain competitive in the global marketplace and improve the quality of life in Europe" (European Commission 2017). Innovation is seen as a driver for the competitiveness of Europe in the global marketplace and leads to all kinds of political efforts to remove rules and regulations that limit the innovation capacity of economic actors. The idea is that in highly industrialized nations, the long-term growth of businesses stems from their ability to continually develop and produce innovative products and services (Sternberg 2000). The European Union is sometimes called the Innovation Union in order to highlight the centrality of innovation in the quest for prosperity of Europe; it creates new jobs, improves the environment and stimulates economic growth.

The economic perspective on the role of innovation in economic growth is also embraced at the firm level. As Christopher Freeman, the doyen of innovation theorists already argued, "not to innovate is to die" (Freeman 1982). This is even more true in an era of continuous change and intense competition where the longevity of products and industries decreases. For this reason, the creation of innovative products and services is often seen as major concern of top executives.

The concept of innovation is applicable to individual persons, economic actors like firms and the economy as a whole, and can be seen as the "emblem of the modern society" (Godin 2009: 5). And yet, it is not clear what exactly is meant with the notion of innovation and its impact on society. Today, society faces the grand challenge of global warming and the call for a more sustainable economy. On the one hand, while the concept of innovation originally concerned novelties in the broadest sense of the word - including imitation, invention, creative

Vincent Blok

vincent.blok@wur.nl

1 Social Sciences Group, Wageningen University, Wageningen, The Netherlands 
imagination, change - it became only recently restricted to technological innovation and commercialized innovation, as the history of the innovation concept shows (Godin 2009). This raises already all kinds of philosophical questions: Why did innovation become so important in twentieth century? Why is innovation technological innovation? Why is innovation commercial innovation and is this necessarily the case? On the other hand, it is exactly this economic paradigm of technological innovation that is at odds with the grand challenge of global warming, as the imperative of economic growth may be seen as 'responsible' for the environmental destruction, resource depletion and impoverishment of populations all over the globe (Blok and Lemmens 2015). This calls for an opening up of the concept of innovation and the philosophical reflection on a concept of innovation that is able to address the grand challenges of our time.

These questions become all the more urgent in light of the emerging concept of responsible innovation. First initiated by the European Union, it calls on all actors involved to consider ethical and social aspects of innovation. The underlying idea is that, by considering socialethical issues in innovation, technological innovations will be developed that not only are economically profitable but also more sustainable, socially desirable and ethically acceptable (von Schomberg 2013; Matter 2011). It is, however, questionable whether innovation can ever claim to be responsible, as long as innovation is deeply ingrained within the conventional economic paradigm (Long and Blok 2017). Is it, for instance, not necessary that we broaden our conception of innovation to includenon-technological innovations and non-market environments? And, to accept alternative strategies of innovation, such as user-based or usercentred innovations, free and open source development, and commons-based peer-to-peer innovation strategies? (Blok and Lemmens 2015)?

To date, there is a clear lack of philosophical reflection on the concept of innovation. While philosophers of technology do not pay attention to the particular context and practice of innovation and focus on new and emerging technologies in general, philosophers of management have shown little interest in the notion of innovation till now. Moreover, almost no article with a particular interest in the concept of innovation is to be found in the tradition of the Philosophy of Management journal. The concept also is missing in Paul Griseri's Introduction to Philosophy of Management. While responsible innovation in the business context has been receiving increasing attention and resulted in various special issues (Scholten and Blok 2015), interest in the field of philosophy of management is lagging behind. This special issue intends to initiate the philosophical discussion about the concept of innovation in general and responsible innovation in particular.

A call for papers was published for a special track under the annual Philosophy of Management conference which was held at St. Annes' College, Oxford 2016. It raised the following philosophical questions to be addressed:

1. What are the advantages and disadvantages of the economic paradigm in the development of the concept of technological innovation, what is the relation between innovation and economic growth/de-growth, and what are alternative conceptualizations of innovation?

2. To what extent is a conceptualization of innovation as beneficial to society legitimate? According to Schumpeter, innovation is the product of creative destruction. The construction of new and innovative solutions is accompanied by the destruction of the old rules and the old order, i.e. the positive impact of innovation is always accompanied by negative impacts elsewhere. How can this 'Faustian' aspect of innovation be 
conceptualized and what are the implications for the concept of responsible innovation (Blok and Lemmens 2015)?

3. To what extent can firms be held ethically responsible in case of innovations with unknown and unintended consequences? Innovations often have consequences and future impacts that are unknown and even unknowable. This raises the question how foresight can be managed in case of unknown future impacts of innovation processes, and how this unknown in innovation has to be conceptualized. Here philosophical concepts like Derrida's l'avenir may be helpful, as well as alternative strategies of gain foresight like hermeneutics (Grinbaum and Groves 2013; Grunwald 2014).

4. What does responsible innovation mean in case of unknown future impacts and what alternative ethical approaches are available to address this unknown future? Here philosophical approaches like Jonas' imperative of responsibility or Levinas' concept of unconditional responsibility may turn out to be relevant (Blok 2014).

5. How to deal with power-, vision-, goal-, sector-, and motive-deviations among stakeholders involved in responsible innovation processes (Blok and Lemmens 2015), and in the development and mainstreaming of new and emerging technologies like genetic modification, nanotechnology or synthetic biology (Blok 2014; Macnaghten and Chilvers 2013).

6. How do stakeholders become mutual responsive to each other and how do they develop societal and ethical norms for responsible innovation, given investment- and risk imbalances and given the remaining information asymmetries among stakeholders involved in commercial innovation practices?

This special issue is a collection of some of the selected works that the track contained and a first effort to address part of the research agenda. All articles are contextualized in the current debate about responsible innovation, and can be read as reflections on the concept of innovation in order to enhance and secure more responsible innovation in the future. While the first three articles can be read from the perspective of the first point on the research agenda, concerning the relation between economy and innovation, article four to six can be read from the perspective of the third point on the agenda, concerning the relation between responsibility and innovation.

In line with recent literature in the field of responsible innovation (Long and Blok 2017), Schlaile et al. (2018) and Hühn (2018) assume that the economic paradigm is a barrier for responsible innovation. But rather than looking for alternative conceptualizations of innovation, as was suggested in the research agenda, they both provide an alternative conceptualization of economy which is better aligned with the notion of responsible innovation. Hühn (2018) criticizes the mainstream interpretation of Adam Smith that radical selfishness can be seen as central market mechanism, and argues that the sympathy manoeuvre is Smith's real market mechanism. Based on Smith' notion of sympathy, Hühn articulates a notion of innovation as social construction, rather than selfish destruction, that could help to build a firmer theoretical basis for responsible innovation. In similar vein, Schlaile et al. (2018) propose an evolutionary economic approach to innovation in order to enhance and secure responsible innovation. In their evolutionary economy approach to innovation, consumers play a crucial role in the creation and diffusion of responsible innovation. While Schlaile and colleagues and Hühn focussed on alternative conceptualizations of economy in order to achieve higher levels of responsibility, Moussavi and Kermanshah (2018) focus on the widespread notion of the innovation system approach. By reflecting on the nature and 
evolution of the innovation system approach and its epistemological foundations, they criticize the theoretical soundness of the approach and show pathways to a more robust theoretical underpinning of the innovation system approach that can also be better aligned with the requirements of responsible innovation.

The point of departure of the contributions by Sand (2018), Kamishima et al. (2018) and Hammershøj (2018) is the lack of control of the outcomes and negative impacts of innovations. While Sand (2018) and Kamishima et al. (2018) focus on the input of the innovation process and propose virtues and capabilities in order to enhance responsibility, Hammershøj (2018) focuses on the throughput of the innovation process and reflects on the role of moods in the responsible innovation process. According to Sand's (2018) virtue ethical approach, virtues have a positive value for managing the opaqueness of innovation processes and should be mandatory for actors involved in responsible innovation. In the context of artificial intelligence (AI) robotics, Kamishima et al. (2018) propose a combination of the capability approach in ethics and the effectual process model in the entrepreneurship literature in order to integrate the collaboration with stakeholders in the design process of innovative companies and achieve higher levels of responsible innovation. Contrary to the focus on the actors involved in the innovation process in the previous contributions, Hammershøj (2018) focusses on the innovation process and highlights that the innovation process is affective in nature. Both creativity and innovation processes are based on the moods of disturbance and enthusiasm. Creativity is based on the feelings of interest and irritations, whereas innovation is based on the feelings of desire and anger. Hammershøj (2018) shows how these moods can play a role in the ethical appraisal of innovations and their possible negative impacts.

With this special issue, we hope to initiate philosophical reflection in this particular field in the philosophy of management domain. At the same time, the collection of articles clearly shows that the philosophical reflection on this topic just started. In addition to the proposed research agenda, the various contributions lay out the ground for further philosophical reflections and discussions in the future.

\section{References}

Blok, V. 2014. Look who's talking: Responsible innovation, the paradox of dialogue and the voice of the other in communication and negotiation processes. Journal of Responsible Innovation 1 (2): 171-190. https://doi. org/10.1080/23299460.2014.924239.

Blok, V., and P. Lemmens. 2015. The emerging concepts of responsible innovation. Three reasons why it is questionable and calls for a radical Transoformation of the concept of innovation. In Responsible innovation 2: Concepts, approaches, and applications, ed. B. Koops, I. Oosterlaken, J. van den Hoven, H. Romijn, and T. Swierstra, 19-35. Dordrecht: Springer International Publishing.

European Commission, cited from http://ec.europa.eu/research/innovation-union/index_en.cfm?pg=why (last Accessed 15-Oct-2017).

Freeman, C. 1982. The economics of industrial innovation. 2d ed. Cambridge: MIT Press.

Godin, B. 2009. Innovation: The history of a category. Working paper.

Grinbaum, A., and C. Groves. 2013. What is "responsible" about responsible innovation? Understanding the ethical issues. In Responsible Innovation, ed. R. Owen, M. Heintz, and J. Bessant. London: Wiley.

Grunwald, A. 2014. The hermeneutic side of responsible research and innovation. Journal of Responsible Innovation 1 (3): 274-291. https://doi.org/10.1080/23299460.2014.968437.

Hammershøj, L.G. 2018. Conceptualizing creativity and innovation as affective processes: Steve jobs, Lars von trier, and responsible innovation. Philosophy of Management 17: 1.

Hühn, M.P. 2018. Responsible innovation: A smithian perspective. Philosophy of Management 17: 1.

Kamishima, Y., B. Gremmen, and H. Akizawa. 2018. Can merging a capability approach with effectual processes help us define a permissible action range for AI robotics entrepreneurship? Philosophy of Management 17: 1. 
Long, T., and V. Blok. 2017. When the going gets tough, the tough get going: Towards a new - More critical Engagement with responsible research and innovation in an age of trump, Brexit, and wider populism. Journal of Responsible Innovation 4 (1): 64-70.

Macnaghten, P., and J. Chilvers. 2013. The future of science governance: Publics, policies. Practice. Environment and Planning C: Government and Policy 31. https://doi.org/10.1068/c1245j.

Matter. 2011. A report on responsible research \& innovation. Available at: http://ec.europa.eu/research/sciencesociety/document_library/pdf_06/rri-report-hilary-sutcliffe_en.pdf.

Moussavi, A., and A. Kermanshah. 2018. Innovation systems approach: A philosophical appraisal. Philosophy of Management 17: 1.

Sand, M. 2018. The virtues and vices of innovators. Philosophy of Management 17: 1.

Schlaile, M.P., M. Mueller, M. Schramm, and A. Pyka. 2018. Evolutionary economics, responsible innovation and demand: Making a case for the role of consumers. Philosophy of Management 17: 1.

Scholten, V., and V. Blok. 2015. Responsible innovation in the private sector. Introduction to the special issue. Journal of Chain and Network Science 15 (2): 101-105.

Sternberg, R. 2000. Innovation networks and regional development-evidence from the European regional innovation survey (ERIS): Theoretical concepts, methodological approach, empirical basis. European Planning Studies 8 (4): 389-407.

Von Schomberg, R. 2013. A vision of responsible research and innovation. In Responsible innovation, ed. R. Owen, J. Bessant, and M. Heintz, 51-74. London: Wiley.

Vincent Blok is associate professor in Business Ethics and Responsible Innovation at the Management Studies Group, and associate professor in Philosophy of Management, Technology \& Innovation at the Philosophy Group, Wageningen University (The Netherlands). Blok's research group is involved in several (European) research projects at the crossroads of business, philosophy and innovation. Blok's work has appeared in Journal of Business Ethics, Organization \& Environment, Business \& Society, Journal of Cleaner Production and other journals. See http://www.vincentblok.nl for more information about his current research. 